\title{
After Interpretation No. 748 in Taiwan
}

\author{
Chin Shen \\ Ph.D. Student \\ Graduate School of Core Ethics and Frontier Sciences \\ Ritsumeikan University \\ JAPAN
}

\begin{abstract}
This paper analyzes some legislative options of same-sex union in Taiwan after the publication of Interpretation No. 748, the Same-Sex Marriage Case in May 2017. The author will focus on three possible legislative options and try to figure out the best way to implement the demand of Interpretation No. 748. As to discover the most likely solution, this paper takes the German Civil Partnership law as a model of reference for two reasons. First, the Taiwan Civil Code has been compiled based on German laws. Second, the German Civil Partnership law is a successful case passed in 2001 and legalized same-sex marriage in June 2017. This paper argues that a step-bystep legislation is the most plausible approach to provide same-sex partners with legal protection. It could ensure same-sex couples to gain social acceptance progressively while traditional social values will still be preserved.
\end{abstract}

Keywords: same-sex marriage, LGBT, homosexuality, sexual orientation, German civil partnership law (Lebens partnerschaftsgesetz-LpartG)

\section{Introduction}

This paper proposes an analysis of the legislative options open to Taiwan after the publication of constitutional Interpretation No. 748 (Declaration of Freedom of Same-Sex Marriage), which created an opportunity for legal reform, it is not only an important milestone in marriage equality but also an important contribution to the promotion of human rights protection in Taiwan. Although there have been many amendments to the Constitution since its enactment in Taiwan, most are found only in the 10th Article of the Amendment Provisions of the Constitution ${ }^{1}$. They declare the state's obligation to protect specific human rights in a basic state policy and do little to add or delete constitutional provisions in response to the expansion or transformation of human rights ${ }^{2}$. Thus, on the legal level, it rarely touches emerging human rights issues that have developed in the world for more than a decade. Prior to Interpretation No. 748, research in the legal circle in Taiwan did not completely disregard the issue of homosexuality, but only addressed it partially rather than comprehensively; still there is little discussion from a legal viewpoint. As a result, most studies are unable to explore the issue in a multifaceted manner. It must be said that this is a flaw in the study of this topic by the Taiwanese legal scholars (李震山, 2007) . However, over and above compliance with constitutional Interpretation No. 748, same-sex marriage is a social issue that urgently needs to be resolved. Regardless of the issue's positive or negative impact on society or of the method to guarantee protection in the future, some form of legal adjustment is needed.

On the contrary, in other countries, especially in Europe, there is already a relatively large quantity of research and legislative cases concerning this issue. In this author's opinion that, if it is possible to compare the European and Taiwanese legal models and comprehensively analyze the conditions needed for homosexual rights protection in Taiwan as well as legal and social issues that may arise in future legislative directions, there will be a breakthrough in research scope. Moreover, the study of same-sex marriage is not an isolated issue; if there is too much focus on the "issue itself," other related real-life social problems will inevitably being ignored.

\footnotetext{
1Additional Articles of the Constitution of the Republic of China (Article 10): Published on 2005/6/10. Afterward, amendments were made successively in1992/5/28, 1994/8/1, 1997/7/21, 1999/9/15, and 2005/6/10. Theyinclude economic Development, Assistance to Small and Medium-Sized Enterprises, Guarantee of women, the handicapped and aborigines. 2At present, the human rights listed in the Taiwanese Constitution are mostly limited to civil rights and political rightsin the classical sense.
} 
Now that Interpretation No. 748 has been made public, the government can no longer ignore Taiwan's lack of legislation on the issue of homosexuality; whether to take a direct legislative path under the existing legal framework or to select a phased legislative path, from a more realistic and long-term perspective involves not only theory, but also to take into account many difficulties in society and legal practice. Fundamentally speaking, the government must take the legal applicability and subsequent social problems into account.

A system constructed by law must take into consideration the stability and sustainability of society which are dependent on shared identity and values. That is, social identity and legal development have always been in a process of mutual influence. The content of law usually represents social identity. Therefore, if there is a lack of universal social recognition, there will be a great difficulty in the formulation and application of laws; whether same-sex marriage can be successfully constructed and the adequacy of future legislative decisions remains key issues.

Academic and social studies on homosexuality in Taiwan have not yet become comprehensive and mature. In order to guarantee human rights through constitutional interpretation, we must face the conflict and differences in values between policy and public opinion. Therefore, after the constitutional interpretation of the Supreme Court, how to propose a complete, transparent, and exhaustive discourse in order to truly embed the relevant human rights into the constitutional normative system will be the focus of this article. In order to better implement future legislation, such analysis and discussion of the issue will help us to clearly understand the possible legislative trends of same-sex marriage in Taiwan. The analysis proposed in this article hopes to provide some inspirations for future same-sex research.

\section{The Same-Sex Marriage Case}

The same-sex marriage question in Taiwan was brought to the court by two petitioners, the Taipei City Government and gay rights advocate Chi Chia-wei. Chi petitioned a judiciary interpretation by the Justices of the Constitutional Court as to the constitutionality of "the impossibility of legal marital relationship between two persons of the same-sex" based on Chapter 2 Marriage, Part 4 of the Civil Code. The other petitioner was the Taipei City Government, which had been brought to court for administrative proceedings by same-sex couples, as authorities had been rejecting applications for same-sex marriages based on the Civil Code clause. Now the Taipei City Government was also seeking clarification as to whether marriage permitted only between a man and a woman was in violation of constitutional guarantees of personal freedom and the right to equality.

Taiwan's constitutional court heard on March 24, 2017, a case which would make Taiwan the first country in Asia to allow ${ }^{3}$ same-sex marriage and, ruled that the current Civil Code provision which did not allow same-sex marriages was unconstitutional. Taiwan's parliament now will have to amend the existing laws or pass new legislation within two years.

The marriage equality movement that had pushed this issue to an unprecedented point made that achievement possible through equality legislation promotion over ten years. However, there are many opinions and disputes to be resolved, concerning the legislation model, the practice and application of the laws and relevant issues during the period determined by Interpretation No. 748. It announces that new legislation should be implemented within two years, otherwise at the end of that period two persons of the same-sex who intend to marry shall be allowed to have their marriage registered by the authorities in charge of household registration according to the provisions of the existing law. In order to solve the personal rights, property rights and other issues which are involved in samesex marriage, due in part to historical and cultural factors, many types of legalization for same-sex marriage have been proposed by scholars and legislators.

\section{Proposition of Legislation Model in Taiwan}

According to Interpretation No. 748 the legislature must complete the law amendment or new law formation within two years from the release of the Interpretation. How to create the relevant legislation is under discussion and people's imagination ranges from various drafts of modifications of the Civil Code, drafts of specific law, to other propositions.

3The current provisions of the Civil Code do not forbid same-sex marriage explicitly, however, articles do not include the marriage of two same-sex individuals. By the Interpretation No. 748, same-sex marriage in Taiwan can, or rather must be legalized.

172 
At present, there are three major propositions: 1) revising the provisions of Marriage Chapter of Civil Code; 2) drawing up a new specific chapter in the Civil Code without changing its existing structure; and 3) drawing up a specific law for same-sex marriage separately.

\subsection{Revising the Marriage Chapter of the Civil Code}

Even before Interpretation No. 748 was published, several drafts for revising the Marriage Chapter of the Civil Code to ensure marriage equality had been proposed ${ }^{4}$, including the Civil Code amendments for marriage equality proposed by Legislator Yu Mei-Nu, Julian Kuo and Jason Hsu and the New Power Party. These amendments were submitted to the Judiciary Committee and Organic Laws and Statutes Committee successively, and a crossparty comprehensive Civil Code amendment was finally examined in Legislative Yuan ${ }^{5}$ in December 2016 after negotiation by the both sides ${ }^{6}$. They aim to revise the Civil Code by adding legal regulations to the effect that the rights and obligations of a marriage are equal for the union of two same-sex individuals or of heterosexuals.

Two same-sex persons shall be allowed to marry without any revision of the original provision that allow two persons of different gender to marry. There is also an anti-discrimination clause in the adoption proceedings stating that the court shall treat an adopter without any discrimination due to her/his gender, sexual orientation, gender identity, gender traits and so on. The proposition advocates that all rights and obligations of current marriage system for the two persons in a heterosexual marriage and those between them and a third party shall be applicable to same-sex marriage. Thus, the same-sex marriage can obtain comprehensive legal protections identical to that of for the current marriage system, to achieve real marriage equality.

\subsection{Drawing up a specific chapter in the Civil Code}

This draft was proposed by Legislator Tsai Yi-Yu and examined in Legislative Yuan in December 2016 ${ }^{7}$. It aims to add a chapter, Same-sex Marriage, in the Civil Code (Chapter 8 Family), and three additional provisions concerning rights, obligations, relationship, inheritance, adoption, and other legal issues relative to same-sex marriage. Like the previous proposition, it also includes equality application clauses. Since revising the Civil Code directly may cause more social disputes at least at first, the proposition advocates to add a specific chapter in the Civil Code for same-sex marriage to achieve the same protections without any revision of the original provisions or the architecture of the current marriage system. The goal is to create a compromise, generating minimum negative impacts and achieving maximum consensus, so that it may be the most feasible proposition in the future.

\subsection{A Civil Partnership Law, a specific law for same-sex marriage}

Although in this case no relevant draft has been proposed, the topic has been discussed. Underlying this proposal is the idea that any direct revision of Civil Code will challenge the essence of the current marriage system and cause social conflicts. In addition, the direct revision of Civil Code would likely lead to amendments and be examined for a long time, perhaps even more than ten years to ensure its legitimacy, in consequence, it is argued that the issues raised by same-sex marriage cannot be solved through the revising existing Civil Code provisions. Therefore, this proposition advocates adopting a model similar to that of other countries for progressive legislation by first drawing up a specific law, then revising the Civil Code and amending the legal system.

\section{What is the best option for same-sex marriage in Taiwan?}

\subsection{Interpretation No. 748}

\subsubsection{Taiwan's culture and same-sex unions}

4Advocates by correcting but not ruining the current system of marriage law in Taiwan, expects to establish the right of marrying without restrictions or, in the broader sense, having a family as a fundamental right and secured under the constitution, and to prohibit the discrimination regarding one's sex, sexual orientation, and sexual recognition. For instance, "husband and wife" has been corrected to "spouses"; "father and mother" to "parents" (Taiwan Alliance to Promote Civil Partnership Rights [TAPCPR], 2013).

5The unicameral legislature in Taiwan, which is equivalent to Congress or Parliament.

6The $24^{\text {th }}$ Committee meeting minutes of Judiciary and Organic Laws Committee in the $2^{\text {nd }}$ session since the $9^{\text {th }}$ appointed dates [The 24th Committee meeting of JOLC], 2016.

7The 24th Committee meeting of JOLC, 2016. 
Before the Interpretation No. 748 was announced, as we have just seen several drafts for revising the Marriage Chapter of the Civil Code to ensure marriage equality had been proposed. However, due to the overwhelming opposition at the time, proposals to amend the Civil Code only passed their first reading and have not progressed further in the legislature. In the face of fierce clashes between the advocates and opponents, Chi brought his case to this Court for constitutional interpretation.

Historically, Taiwan's marriage system has been modified several times as far as law-making is concerned and the push for same-sex marriage may be seen as the next step in a long-term evolution. For example, the traditional customs of "the wife adhering to the husband", which Article 1002 of Civil Code states as that wives should use husbands' residence as their residence, was declared in violation of the Constitution by interpretation No. 452 in 1998. ${ }^{8}$ Similarly, the regulation of the original Article 1059 of Civil Code according to which children should use the father's surname has been revised in 2007 by the regulation on "gender neutralism", according to which children can use either the father's or the mother's surname (Ching-Tian, Chen, 2008).

The modification of laws, like these ones, gradually smashed unequal regulations concerning gender that were originally present in the Civil Code. That is to say, the demand for revolution in marriage has existed in Taiwanese society for a long time and has led to progressive modifications of the laws (Li-Ju, Lee, 2007). Once again when facing the issue of same-sex marriage in Taiwan now, we are going back to the level of "marriage revolution' and a new demand for "creating a multiple relationship" appears. The difference between the previous revolution and this new revolution is that it expands change from the original focus on opposite-sex marriage to include same-sex marriage.

When the Justice tried to respond the objection relative to the "family ethic in Chinese tradition", he claimed that: "If the function of marriage is considered to be the protection and reproduction of offspring, the focus (on heterosexual marriage) does not come without any reason. However, in the chapter on marriage the key element in permitting opposite sex marriage is not fertility; a marriage is not defined to be invalid and that it should be canceled, nor a cause for divorce if the couple is found to be infertile or unable to have children after getting married. This means reproduction, offspring is not essential tor marriage." On the other hand, "the consideration (on traditional Chinese family ethic) will be proper ${ }^{9}$ if marriage is to maintain basic ethical orders, such as age for getting marriage, single spouse, forbidden marriages in proximity of blood, fidelity obligation, and duty of maintenance."

In addition, the Justice also declared that "same-sex marriage" does not change the existing social order established by opposite-sex marriage; marriage freedom of two people of the same sex can further become the foundation of stabilizing society after it is admitted formally by law." Even though the judge avoided the dispute of "surrogate pregnancy" or "adoption" by same-sex partners, we can still say that this Interpretation opens up and includes same-sex marriage into the stable family system. It looks like this interpretation is "re-writing" the definition of family, but with the aim of fulfilling the ethical order of a stable society.

\subsubsection{The social and political dimensions of Interpretation No. 748}

The following three points clearly appear in the interpretation statement by the Justice:

(1) Maintaining the good structure of the social order

We should not neglect the fact that homosexuals (LGBT) exist in society. However, the current laws pay no attention to these people, so that they can't be protected by the law when they suffer injustice. In consequence some people escape from legal punishment for reprehensible actions. This has a negative impact on this minority groups and other people in society. Homosexual's rights must be guaranteed and protected and should be regulated. Setting up the laws for these rights and interests respects the Constitution and is consistent with human rights and equality pursuit; it can unite and stabilize society.

(2) Reduce social discrimination

Prejudice and slander have existed against homosexuals for a long time. These forms of rejection prevent them from developing their self-value and even ruin their dignity. However, our society is in a movement to draft samesex marriage law and this is an important element to reduce discrimination. 
In fact, law-making and discrimination elimination interact and exist side by side; reducing discrimination provides protection that allows the effective fulfillment of law.

(3) For a sound legal system

Legal voids lead to unsolvable problems or blind points that cannot effectively be corrected rapidly. Moreover, the more the law system and structure are complete, and the less social contradiction and conflict there will be.

In other words, this interpretation gives members of society who support same-sex marriage very good reasons to propose modifying the content of the chapter on marriage in the current Civil Code in view of including same-sex marriage. However, we have to recognize that same-sex marriage (marriage equality) is a very difficult issue among legislation problems that humans face. Because the "family" is a very fundamental institution same-sex marriage might change its organization to which people have become accustomed and some people may think that any change is inadvisable, if not impossible. Legislation is an activity of formulating, recognizing or changing the specific social regulations using laws bearing on specific subject, according to a given position and program. In another word, law making should comprehensively consider various aspects of a problem, such as history, politic, economy, habit, and traditional culture, as well as the issue of the psychological acceptance by people at large (Tomuschat, 2014).

Specifically, in the social issue of same-sex marriage, its law-making should definitely consider the complex dimensions of legislation explicated above. Although people who support same-sex marriage legislation aggressively claim that being homosexual is a kind of natural status and deny that it is related to moral issues, we must consider the impact of such legislation on traditional culture and the opinion of the public, as well as accepted cultural values when choosing the law-making mode for same-sex marriage in Taiwan. Ignoring the impact of traditional culture, the opinion of public cultural value and the psychological acceptance by people will negatively affect the public's recognition of this law and the effectiveness of the new legislation. As a consequence, modifying the Civil Code to include same-sex marriage is not a bad strategy, but we also need to take into account the objecting voices and differing opinions (Barker \& Monk, 2015, Chang, 2005).

Although there are, as we have seen, several modifications drafts of the Civil Code that have been proposed in Taiwan, the government might not accept them. It is because opposing voices and non-supportive views are still too strong, and the government might feel it needs to be cautious.

\subsection{Not doing anything}

First, considering that the Justice announced that should the legislature fail to promulgate a new law or modify existing legislation within two years after the publication of the constitutional interpretation, same-sex partners will be able to legally register their marriage, it follows that, another possible direction in which the same-sex marriage issue may evolve in Taiwan is that the legislature takes no further action or fails to complete legislation or law modification within the deadline.

If so, it seems that same-sex partners will be able to register their marriage according to the interpretation of the justice as long as the two-year threshold is reached. However, this potentially "wonderful" prospect might also have some risk of "failure". What kind of "failure" might it face?

In fact, such an attitude on the part of the legislature would be to turn away from the actual political reality of Taiwan, making it unable to attain an important political objective (giving same-sex marriage a legal status, but no political status). Without a relevant law, the registration office could refuse to approve the marriage applications of same-sex partners, even if these couples could then accuse the household registration office of violating the constitution. Because inaction on the part of the legislature would make the Justice's announcement on same-sex marriage exist in name only. Therefore, attaining same-sex marriage two years later through "doing nothing" may look like a possible direction, but it is likely that it will not be successful in reality. It gives to the two-year deadline for the revision of law only a symbolic, but not a substantive significance. It is somewhat as if the legislature were saying, Interpretation No. 748 did not really happen, this is not an issue which requires any attention, we will just let people who are interested in it deal with it individually.

Besides, for those partners who want to raise a child, they would face the problem of family rights (Caracciolo \& Masselot, 2004, Turbe, 2003). Nowadays the family rights are based on the concept that a family is a companionship of "fatherhood", "motherhood" and "child". There is a list of laws which point out the rights and obligations that a "father" and a "mother" should obey. 
However, same-sex partners cannot be distinguished with the concepts of "fatherhood" and "motherhood" as the exist in present family laws for they are cannot be classified as "father" or "mother" in a clear and distinct way. Furthermore, what are the rights (and obligations) of children to their biological mother or father (and of the biological parents to the child)? Who is not a member of their family? or is he/she (the child or the parent) a member of the same family? Therefore, if there are no any changes in family rights, same-sex couples and their children cannot be protected ${ }^{10}$.

\subsection{A specific law for same-sex marriage}

Homosexuals are gradually being given the same rights and opportunities as heterosexuals. However, there is no consensus yet on the issue of same-sex marriage, there is no universal standard before the legislation. The legislators attempt to find a balance between the universality of human rights and cultural relativism. Reviewing the reform of the marriage system or the establishment of the same-sex marriage law, the pros and cons should be weighed carefully.

The legalization of same-sex marriage has precedents in Western countries. Due to different social and cultural backgrounds in different countries, the choices of legislation are very different (Eskridge, 1993). In addition to Civil Marriages, some countries adopted a Civil Partnership Law ${ }^{11}$ to recognize same-sex marriages. This measured method has provided recognition and legality to the union of same-sex couples, to ensure that they have the same rights and obligations as married heterosexual couples. It can be seen that some Western countries have apparently reached a consensus on the legal recognition of same-sex marriage, and the consensus of the society is very important for same-sex couples to have the corresponding legal rights and obligations in Taiwanese. Therefore, it is also necessary to consider among future legislative choices Civil Partnership Law as an option.

\section{A precedent for the specific law for same-sex marriage system: a same-sex Partnership Law}

\subsection{German Civil Partnership Law}

The specific law for same-sex marriage advocated by some people, the Civil Partnership, is not a new type of legislation. It has been established in Europe for years. The scholars and legal professionals advocating this proposition also think that the future law should be drafted in reference to the systems already in place in some European counties. The present section will analyze the German Civil Partnership law which was already passed in 2001,since the Taiwan Civil Code has been base on the reception of German laws for a long time（台灣法學 會台灣法學史編輯委員會，2012；王澤鑑，2016）. Moreover, in June of 2017, Germany legalized same-sex marriage, so that same-sex couples are now able to marry enjoying full rights, including the adoption of children. Therefore, it is worth analyzing the German legislation model for reference.

In 2001, the Same-sex Partnership Law, Lebenspartnerschaftsgesetz-LpartG, was passed in Germany. This law, as indicated by its name, is specific for same-sex partnership. Before that, marriage in Germany was restricted to man and woman couples. The Paragraph 1, Article 6, of German Constitutional Law, Grundgesetz, expressly states that marriage is restricted to man and woman couples. According to this basic principle, the union of two same-sex persons is prohibited. Through numerous disputes and long-time negotiation, the same-sex Partnership Law was adopted. This law which is specific for and only applicable to homosexual was created on the basis of an original basic principle. This Law grants to same-sex civil partnership unions most of the rights and obligations of traditional marriage, but for adoption of children（戴㻦如，2004）. In 2017, the German Bundestag went further and finally voted and passed the legalization of same-sex marriage.

Like the original German marriage system, the contents of the Same-sex Partnership Law are referred to or applied through the regulations of Civil marriage. Below is a short summary of its main provisions:

(1) Elements of foundation: They are similar to those of marriage, including that both of the same-sex persons shall declare they are willing to enter into this Partnership and complete the registration with the household administration authority with mutual understanding.

10Of course, the same issues arise in the case of explicit same-sex marriage legislation, but it is normal to assume that the legislation would address these issues, while not doing anything would simply turn a blind eye to the difficulty. 11Example of such legislation are France's "Pacte civil de solidarité" (PACS) in 1999 and Germany's

"Lebenspartnerschaftsgesetz-LpartG" in 2001.

176 
(2) Fidelity Obligation: The purpose of marriage is permanent communal living. Both of the partners shall obey the fidelity obligation for one another. Neither party may marry or conclude a partnership with others.

(3) Property System: The property system shall be agreed by the both of partners and specified by the scope of the Civil Code. Without any specified agreement, the legal property system is applicable.

(4) Rights and Obligations: According to the Article 3 of German Constitutional Law, Protection for Right of Equality, the rights and obligations for the persons of same-sex marriage with legal registration shall be as the same as those for the persons of heterosexual marriage.

(5) Right of Inheritance: It is basically the same as it is for heterosexual marriage with specific exceptions and differences.

(6) Dissolution of Relationship: The residual property in need of process shall be distributed in accordance with the agreement of the partners. After the dissolution of relationship, each party shall be financially responsible for herself/himself in principle, and the party without the capability to do so by herself/himself may ask the other for maintenance.

The differences with marriage are the following:

(1) Subject Limitation: The subjects to whom the Law applies are same-sex partners only. Persons of different gender can only form a couple through marriage.

(2) Restricted Conduction: The scope of restricted conduction for same-sex partners is smaller. Two same-sex persons who are direct blood relative or full/half blood brothers or sisters shall not be allowed to enter in partnership.

(3) The same-sex persons of the partnership shall live together in principle and take maintenance obligation in the case of separation. The rights of access to family facilities, house, and others have been specified in law. Separation for a certain period of time may constitute the cause for dissolution of partnership.

(4) Adoption: The same-sex persons of partnership shall not be allowed to adopt a child jointly. Each of them may adopt a child independently ${ }^{12}$.

(5) Dissolution: In Germany, more strict elements are required for divorce. Only persons in an objectively broken and irretrievable marriage are allowed to divorce, a condition which shall be judged by the court, and divorce is not something partners can do directly by themselves without mutual consent. The dissolution of partnership is almost same as that of marriage. Considering the willingness of the parties, the dissolution shall also have to meet the following requirements:

a. The partnership shall be revoked by the court in case the parties have in mutual consent, been separated for one year or more, and have no expectation of renewing their partnership, or

b. The partnership shall be revoked by the court in case that one party claims that continuing living together may lead to harsh conditions due to the other party, and the parties have been separated for three years or more.

(6) Taxation System, Immigration and Insurance: These have been specified in the regulations of Lebens partner schaftsgesetzergänzungsgesetz which has not been passed. Marriage law provides married couples advantages in relation to taxation ${ }^{13}$. With the new law recently passed, it is not the case anymore.

\subsection{Why did Germany introduce the Same-sex Partnership Law?}

The main reason why Germany introduced Same-sex Partnership Law was to eliminate discrimination against same-sex couples. Long before this act was enacted, affirmation of same-sex couples had been on the rise throughout the country. However, at that time, conservatives and those opposed to same-sex union were still the majority. It was not until the decriminalization of sexual behavior among gay men in Germany that the consensus was gradually reached on research and promotion of equal treatment towards same-sex couples and marriage. ${ }^{14}$

12BT-Drucks 14/3751: In its final resolution of chamber of representatives (Der Deutsche Bundestag), took a conservative view into consideration that "children should be protected," it is also believed that the relevant provisions should be provided to protect children from unstable life.

13BT-Drucks 14/4545: The referred Same-sex Partnership Law does not influence the benefits of the federation and can be approved without the resolution of Senate (Der Deutsche Bundesrat) See previous commentary note 14. However, this proposal (Lebenspartnerschaftsgesetzergänzungsgesetz) was rejected by Bundesrat because it involved issues related to taxation system, immigration and insurance.

14Paragraph 175: The East German government abolished the "gay crime" in 1968, while the left-wing Social Democratic Party in West Germany taking office after the 1969 election temporarily suspended the arrest under Paragraph 175. 
As the same-sex couples living together for a long time had never been allowed to obtain legal status and protection, they encountered unfriendly people, In the process of self-identification, they had to endure derogatory labels. Furthermore, when same-sex couples suffered from cancers, AIDS, or other catastrophic illnesses, major problems aroused, such as the obligations to support each other, the consent to operation from one partner, or the inheritance after a partner's death, and other questions of rights. With the change of the political system, the German government gradually attached more importance to the rights and obligations of same-sex couples in real life. It began to explore the legal changes in marriage and the recognition of same-sex couples, in the hope of changing the status quo in a legal manner and of encouraging greater acceptance of same-sex couples (Levitt, 2000).

Nonetheless, at that time there was no consensus within the German government as how to legally address these issues. Conservatives and opponents to same-sex union believed that the definition of marriage based on Article 6 of the Basic Law of the Federal Republic of Germany should not be changed, while some homosexual groups opposed the legalization of same sex unions, holding that "choosing marriage and monogamy is nothing but to follow the mainstream. Resulting in that instead of the more liberalization you want in the same-sex union, you would have more bounds by law”（林秀蓮、賴俊兆, 2016）. Although at the time, the public's acceptance of same-sex marriage increased, age-old customs, cultural inheritance, and the fear of new things still conflicted with such a potential change.

Therefore, the German government while dealing with this issue focused on political stability and ensured that the law-making did not conflict with social reality, in the hope that, through step-by-step legislation, social acceptance of same-sex couples could change while a mainstream space for opposing parties and social values was reserved. It also took into account the strong consensus that anti-discrimination campaigners fostered to help same-sex couples earn both political and legal rights. As a result, a Same-sex Partnership Law based on "moderation" and "harmony" came into being.

\section{Importance for Taiwan}

In Germany, the acceptance of homosexuals has improved, and the union of same-sex partners became popular （林秀蓮、賴俊兆，2016；張婉慈，2017） after the implementation of the Same-sex Partnership Law. Even though there are still stigmas and prejudices towards homosexuals in some places, overall it can be said that the Same-sex Partnership Law was successful in Germany. Therefore, many people advocating the specific Same-sex Partnership Law in Taiwan believe that something like it can be politically and legally expedient to promote the union of homosexuals without changing the essence of traditional marriage.

What is the best way to promote and implement protection of rights and interests for same-sex partners? What are the difficulties and solutions that may be encountered in the legislative process? In addition, how will the situation be changed after the actual adoption of the legislation? The effectiveness of the Same-sex Partnership Law in Germany suggests that it may be worthwhile for Taiwan to learn from that experience. However, we cannot just follow like sheep and we need to take into account the political and cultural factors of Taiwan. A law that succeeded in Germany will not necessarily apply to Taiwan.

The formulation of a law should take the social and cultural uniqueness of Taiwan into account, or it will be difficult to create consensus in society, and the law will not be effectively implemented. Therefore, what exactly will Taiwan do in the face of the recognition of same-sex marriage? And what are the possible benefits after the change? The legislative process is bound to have a defining Taiwanese characteristic.

First, the oppression and discrimination of non-traditional relationship or marriage seems stronger in Taiwan than in Western societies. In Chinese society, marriage is mostly a union of two families rather than two individuals, and Taiwanese have to bear social censure and oppression to a greater degree compared to more open, free and tolerant western societies. For example, in Taiwan people who marry late, who do not want to get married, or get divorced are often stereotypically labeled as "irresponsible," "unstable," and "losers," and thus face discrimination and pressure from society.

Nevertheless, homosexuality was not decriminalized until Germany abolished controversial Paragraph 175 in 1994 following the German reunification.

178 
In addition, traditional marriage possesses a more dominant and stable status, compared to other forms of relationships, such as unmarried cohabitation or having a child out of wedlock. These are therefore more often subject to discrimination and oppression, let alone same-sex couples. Moreover, although some people do not want their intimacy to be regulated by any state's public power, it does not mean that they do not want their relationship to be legally protected. Perhaps the "partnership system" option will offer an alternative to the marriage reform in Taiwan.

In coordination with Taiwan's social and cultural customs, people who do not want to enter into marriage or samesex couples but who desire to enter in a legally secure and free relationship, will all be given a choice of "real" intimacy, if the partnership system can be on an equal footing with the institution of marriage and destroy the superiority of traditional marriage in all relationships. This means that in Taiwan Civil Partnership should also be available to heterosexual couples. In other words, when people have other institutional options in addition to marriage, the dominant position of marriage will be shaken and gradually become not the only, superior choice but one of the options for getting married. At the same time, it is also conceivable that the hegemonic status of traditional marriage will gradually weaken, as it is no longer an important basis for evaluating a person's life value, and is not the only social norm that distinguishes "good/bad" groups. In this way, it might really achieve the purpose of expanding the scope of legislative protection. Therefore, we have to ask what the best way to reform the intimate relationship in a non-marital form should be.

At this stage of the policy, in order to reduce social conflicts and antagonisms arising from institutional changes, the distinction of the names between the partnership system and the marriage law system must be maintained (not to change the definition of marriage, but it may raise the objection of "the same essence but a different title"). The lawmakers should focus on the protection of the real rights and interests on same-sex partners in the legislative content, respond to the needs of same-sex partners pragmatically, and improve the plight of same-sex partners. In addition, they should avoid doing this in a roundabout and segmented way, because it may increase the unnecessary burden of law a mending and cause disputes involving litigation. Thereby, it could also lay a solid foundation for further legalization of same-sex marriage in the future.

Furthermore, the author believes that the Taiwan society should also draw up anti-discrimination laws for homosexuals while promoting the partnership system. In addition to the adoption of marriage reform to enable the nation to recognize the legal status of same-sex couples, the anti-discrimination laws for homosexuals can gradually guide people and help dispel stereotypes, improve social acceptance of different groups, and also expand the rights and protection of homosexuals. Moreover, as there is no reason to think that as the partnership law would change people's sexual orientation, the adoption of this law will not have much effect in changing the existing marriage system, family system, and should not be viewed as endangering the traditional social structure and concept. The acceptance and recognition of such a new pattern of family composition may reduce the ongoing conflict on this issue, making it possible for society to accept same-sex partnerships as normal and rendering politics and society relatively stable.

What we can be certain of is that the current marital composition is being transformed because of the changes in culture and people's thinking that are taking place, and thus the law must also be adjusted accordingly. However, clear direction and a concrete framework of the formulation and implementation of the specific law for same-sex marriage (hereafter as Specific Law) are still needed. Although we can employ the legislative experience and normative content of the German Same-sex Partnership Law as a reference, further research is required with respect to the specific situation of Taiwan society, as well as to the content of the Specific Law "applying mutatis mutandis" or "applying" the regulations of the Civil Code on a great scale, whether it can satisfy the needs of diverse relationships still needs further discussion (Chang \&Yeh, 2013).

\section{Conclusion}

In Taiwan, same-sex marriage is not illegal anymore, but simultaneously it is not yet really legal because there is no legislation to address the issue. There is no denying the fact that future legal changes are imperative. The establishment of a Specific Law is of great significance not only for homosexuals but also for all people. It responds positively to the voices and needs of the LGBT community and also brings critical thinking to the traditional marriage system. This different form of the system can be an open-ended way for people's union. Besides, it might lead to the reform of marriage itself. In this way, which might be conducive to shape a new subject of autonomy and self-determination in intimate relationships? However, the revolution of the legal system is not only political; it also has a great influence on culture, society, and even individuals. 
Therefore, what we have to ask is that in addition to the legalization of same-sex marriage empowering same-sex couples, what are, from other perspectives, the positive or negative effects that these changes in the law are likely bring about. The establishment of a Specific Law does offer a wide choice of more diverse relationships, as well as the possibility of breaking the traditional marriage as the only form of intimacy.

However, even if we cannot ensure that such an option will be portrayed as equal to marriage, whether this option really meets the needs of same-sex couples, as well as the imagination of society for equal and diverse relationships, are issues to be discussed and that cannot easily be determined. But what is sure is that the changes of law and of society are inextricably linked and complement one another. In the process of change, if we ignore these problems that have to be faced, we will be responsible for the lack of legal effects and the risk of inciting fierce opposition. Because changes in the legal system are not everything, over the course of promoting reform, we should attach importance to the process of change itself and its far-reaching impact on culture and society (Chang \& Yeh, 2009). "Mere changes" are not the only goal as there is not only one voice in society but many multifaceted perspectives that compete with each other. It is important to respect and listen to different beliefs as well as to deepen communication and discussion. Only through the redefinition of the marriage system and the support of culture and education can the principle of marital equality be truly implemented.

\section{References}

Barker, N., \& Monk, D. (Eds.). (2015). From civil partnership to same-sex marriage: interdisciplinary reflections (pp. 29-44).Oxon, UK: Routledge.

Caracciolo di Torella, E., \&Masselot, A. (2004). Under construction: EU family law. European Law Review, 29 (1), 32-51.

Ching-Tian, Chen. (2008). The Research on the Question of Children's Surname in the Civil Law Article $1059^{\text {th }}$. Journal of Toko University, 3(1), 129-147.

Deutscher Bundestag. (2000). Drucksache 14/3751. Retrieved from https://dejure.org/Drucksachen/Bundestag/BT-Drs._14/3751

Deutscher Bundestag. (2000). Drucksache 14/4545. Retrieved from https://dejure.org/Drucksachen/Bundestag/BT-Drs._14/4545

Eskridge Jr, W. N. (1993). A history of same-sex marriage.Virginia Law Review, 79, 1419-1513.

GLBTQ Archives. (n.d.). Paragraph 175. Retrieved July 08, 2018 from http://www.glbtqarchive.com/ssh/paragraph_175_S.pdf

Justices of the Constitutional Court, Judicial Yuan, R.O.C. (1998). J.Y. Interpretation No. 452. Retrieved from https://www.judicial.gov.tw/constitutionalcourt/EN/p03_01.asp?expno=452

Justices of the Constitutional Court, Judicial Yuan, R.O.C. (2017). J.Y. Interpretation No. 748. Retrieved from https://www.judicial.gov.tw/constitutionalcourt/EN/p03_01.asp?expno=748

Laws and Regulations Database of The Republic of China. (2005). Additional Articles of the Constitution of the Republic of China. Retrieved from https://law.moj.gov.tw/Eng/LawClass/LawAll.aspx?PCode=A0000002

Legislative Yuan, Republic of China (Taiwan). (2016). The 24th Committee meeting minutes of Organic Laws and Statutes Committee in the 2nd session since the 9th appointed dates. Retrieved from https://www.ly.gov.tw/Pages/Detail.aspx?nodeid=4658\&pid=4104

Levitt, S. R. (2000). New Legislation in Germany Concerning Same-Sex Unions. ILSA Journal of International \& Comparative Law, 7, 469.

Li-Ju, Lee. (2007). Family and Gender Equality: A Critical Assessment on Family Law Reform. Chengchi Law Review, 95, 175-227.

Taiwan Alliance to Promote Civil Partnership Rights. (2013). Marriage equality. Retrieved from https://tapcpr.org/marriage-equality/intro

Tomuschat, C. (2014). Human rights: between idealism and realism (pp. 29-39). Oxford,UK: OUP.

Turbe, L. A. (2003). Florida's Inconsistent Use of the Best Interest of the Child Standard. Stetson Law Review,33, 369-399.

Wen-Chen, Chang. (2005). The role of judicial review in consolidating democracies: The case of Taiwan. Asia Law Review, 2(2), 73-88.

Wen-Chen, Chang.,\&Jiunn-Rong,Yeh. (2009). The Changing Landscape of Modern Constitutionalism: Transitional Perspective. National Taiwan University Law Review, 4 (1), 145-183. 
Wen-Chen, Chang.,\&Jiunn-Rong,Yeh. (2013). Judges as Discursive Agent: The Use of Foreign Precedents by the Constitutional Court of Taiwan. In T. Groppi, \& M. C. Ponthoreau (Eds.), The use of foreign precedents by constitutional judges (pp. 373-392).Oxford,UK: Hart Publishing.

戴瑀如（2004）。論德國同性伴侶法。月旦法學雜誌，107，145-165。

台灣法學會台灣法學史編輯委員會（2012）。戰後台灣法學史（上冊）（頁 222-223、235-237）。台北 市：元照出版社。

李震山（2007）。多元、寬容與人權保障一以憲法未列舉權之保障為中心（頁 177-184）。台北市：元照 出版社。

林秀蓮、賴俊兆（2016）。考察法國、德國同性伴侶／同性婚姻法制發展及實務運作情形（頁 32、3536）。法務部法律事務司出國報告。台北市：法務部。

張婉慈（2017）。同性伴侶法制實施之社會影響與立法建議成果報告書（頁 37）。法務部委託專案報告。 新竹市：清華大學科技法律研究所。

王曉丹（2007）。台灣的性別與法律研究。法令月刊，58（4），104-118。

王澤鑑（2016）。法律思維與民法實例一請求權基礎理論體系（頁 229-234、276）。作者出版。 